\title{
Examining the Pedagogy of Entrepreneurship Education and its Contribution in Creating Entrepreneurship Propensity in Kenya
}

\author{
Lucy Maina Kiganane (PhD) ${ }^{1}$, Teresia Ngina Kyalo $(\mathrm{PhD})^{2}$ \\ ${ }^{1}$ The Cooperative University of Kenya, Nairobi-Kenya \\ ${ }^{2}$ Karatina University, Karatina-Kenya
}

\begin{abstract}
In the last decade, the desire for career readiness progammes and courses that can help prepare and equip college and university students with skills that they need for employment as soon as they graduatehas been on the rise globally. Statistics indicate that self-employment is the last career choice for most graduates in Kenya. As one of the most entrepreneurial economies in East Africa, Kenya is to create a globally competitive and adaptable human resource base aimed at meeting requirements of a rapidly industrializing economy by 2030. This can only be achieved by establishing life-long training, education and enhancing networks and collaboration between the industry and entrepreneurship education. Researchers have sought to answer the question of not only what should be taught in entrepreneurshipbut how it should be taught.This paper critically examined thePedagogy of Entrepreneurship education and its contribution in creating entrepreneurship propensity in Kenya. It specifically sought to determine contribution of Mass instruction techniques entrepreneurship pedagogy on entrepreneurship propensity, examine influence of active experimentation method of entrepreneurship pedagogy on entrepreneurial propensity and assess influence of doing experience method of entrepreneurship pedagogy on entrepreneurial propensity. The study adopted a simple random samplingtechnique and data was collected fromselected institutions offering entrepreneurship education using a semi structured questionnaire. Data was analysed using descriptive statistics and multinomial logistic regression analysis. Results indicated that there is a significant influence of mass instruction technique, of doing experience method and active experimentation method entrepreneurship pedagogy on Entrepreneurshippropensity. There are still glaring gaps in the entrepreneurship education-lack of action learning( doing experiment )andthedevelopmentofactualventures, lack of practical skills and a lack of industry relevance in entrepreneurship education, lack of experientiallearning and low level mentoring in Kenya today.
\end{abstract}

Keywords: Entrepreneurship, Entrepreneurship Education, Pedagogy, Contribution, Entrepreneurship Propensity

\section{Introduction}

Entrepreneurship education is an inevitable strategy for inculcating an entrepreneurial culture and orientation in a nation, creating employment, raising individual incomes, transforming communities and enhancing national economic development. Nations that have embraced entrepreneurship have made good progress in addressing the problem of unemployment, and achieved impressive results (Alakbarov, 2010).

Scholars have argued that formal education discourages entrepreneurship as it is designed to prepare students for conventional careers and thus has the effect of reducing rather than increasing creativity and entrepreneurialism (Timmons, 1994; Plaschka\&Welsch, 1990). Notwithstanding these observations, it is generally accepted that where entrepreneurship is taught it does encourage entrepreneurial action (Gorman et al, 1997) or at least intentionality towards entrepreneurial careers (Pittaway\& Cope, 2007).

Jack and Anderson states that the teaching of entrepreneurship is both a science and an art where the former relates to the functional skills required for business start-up (an area which appears to be teachable) while the latter refers to the creative aspects of entrepreneurship, which are not explicitly teachable(Jack \& Anderson, 1998). However, itis generally accepted that where entrepreneurship is taught it does encourage entrepreneurial action (Gorman et al, 1997) or at least intentionality towards entrepreneurial careers (Pittaway\& Cope, 2007).

Carrington Crisp in his study established that rising youth and graduate unemployment in Africa and elsewhere and a significant upsurge in entrepreneurial activity have, to a large extent, undermined perceptions of traditional models of business education. As more people in developing and emerging economies are successfully venturing into business as a pathway to employment, practitioners and educators need to redefine business education in a way that is relevant to the contextual reality of nascent and aspiring entrepreneurs in all Low Income Countries (LICs), including in Africa. This will require a decisive shift from the traditional approach of business schools and their traditional pedagogical models (Carrington, 2011).There is a unanimous agreement among entrepreneurship educators that there needs to be a shift of emphasis from the scientific to the artistic and creative teaching of entrepreneurship. Although the focus of most entrepreneurship courses and training lies in the scientific dimension of entrepreneurship, it has been acknowledged that entrepreneurship education helps ignite the artistic, creative and perceptual aspects of entrepreneurship. (Lee et al, 2007).

Empirical evidence shows that using traditional methods, such as the lecture and its variant "chalk and talk" to teach entrepreneurship education, merely results in a knowledgeable person (Smith \& Paton, 2011), as these methods lack initiative for application. While studies 


\section{International Journal of Science and Research (IJSR) \\ ISSN (Online): 2319-7064}

Index Copernicus Value (2015): 78.96 | Impact Factor (2015): 6.391

vindicate their effectiveness in maximizing the efficiency of teacher-learner knowledge transfer on one hand (Sherman et al, 2008), on the other they demonstrate them to be static, and fail to respond to the naturally dynamic business environment, their utility remains in creating entrepreneurial awareness (Smith \& Paton, 2011).

Entrepreneurship education is about promoting change in attitudes to ,increase the number of students who view „business start-up as a viable career option" (Black, 2003). To succeed in this, entrepreneurship education must be concerned with learning and facilitating for entrepreneurship, not about it (Laukkanen, 2000; Cooper et al., 2004). „The entrepreneurship educational system has to be oriented towards "doing" more than "thinking". Knowledge has to be converted into solutions that benefit customers in the market place ${ }^{e e}$ (Formica, 2002). The learning must be personal, practical and experiential through discovery (Dana, 1993; Gorman, 1997; Fayolle, 2001; Rae and Carswell, 2001; Bird, 2002-2003) therefore, entrepreneurship education is a constructivist based education (Ehrste'n\&Kjellman, 2001) as it includes all activities aiming to foster entrepreneurial mindsets, attitudes and skills and covering a range of aspects such as idea generation, start-up, growth and innovation (Fayolle, 2009).

Entrepreneurship education covers a wide variety of audiences, objectives, contents and pedagogical methods(Fayolle et al, 2008). The most commonly cited objectives of entrepreneurship education by previous studies are: to acquire knowledge relevant to entrepreneurship, to acquire skills in the use of techniques, in the analysis of business situations and in the synthesis of action plans, to identify and stimulate entrepreneurial drive, talent and skill, to undo the risk-adverse bias of many analytical techniques, to develop empathy and support for the unique aspects of entrepreneurship, to revise attitudes towards change, to encourage new start-ups and other entrepreneurial ventures, to stimulate the ,affective socialization element ${ }^{\text {ee }}$ (Alberti et al, 2004).

Kuratko argues that the relevant question is not, ,can entrepreneurship be taught but, what should be taught and

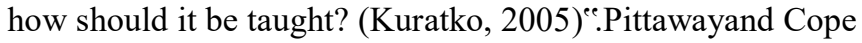
(2007) noted that educators advocate a range of pedagogical approaches including: action learning and the development of actual ventures, new venture simulations, technologybased simulations, skills-based courses, video role plays, experiential learning and mentoring.Honig opined that in considering entrepreneurship education, the pedagogical implications of business plans are paramount and should be of concern to many educators in the field (honig, 2004). In support of this White et al (2010) suggests that an effective method for teaching skills associated with writing a business plan may be achieved through a process of translating academic research into pedagogy that may be useful in the classroom. Moreover, they suggest that in the particular case of teaching skills associated with understanding essential criteria of a business plan, the appropriate pedagogies are similar to those used to teach a craft. A craft is commonly defined as an art, trade, or occupation requiring special skills.
Carrier, (2007); Hindle,(2007)Fayolle et al, (2008) classify the entrepreneurship teaching methods into the following categories: case Study, group discussion, individual presentation, individual written report, group project, formal lectures, guest speakers, action learning, seminar, web-based learning, video recording. The study by Solomon et al (2002) highlighted that the most popular teaching methods in entrepreneurship education are creation of business plans, case studies and lectures.

Research has established that entrepreneurs learn differently from others (Fredrick, 2007; Gatchalian, 2010). They "require active and concrete pedagogical interventions through deepening learning in theory, process and practice of entrepreneurship" (Fredrick, 2007). Mere entrepreneurial awareness cannot develop entrepreneurial practice. To develop entrepreneurial practice requires methods capable of instilling transversal entrepreneurial skills. In tandem with Kolb's experiential learning model (Kolb, 1984), different learning opportunities for optimum development of the various students ${ }^{\text {ee }}$ entrepreneurial capabilities have to be designed into curriculum delivery. It is argued that the success of entrepreneurship education is influenced by the teaching and assessment methodologies used in delivering entrepreneurship education lessons, teachers ${ }^{\text {ee }}$ personal interaction with entrepreneurship practitioners, and the availability of training resources (Maina, 2006; Pihie\&Bagheri, 2011)

Kenya ranks among the most entrepreneurial economies in East Africa, an environment characterised by a relatively high level of provision of skills required for enterprise development (Garavan\&O ${ }^{\circ}$ Cinneide, 1994). This orientation is informed by concepts of entrepreneurship education, which acknowledge that although some people may be exceptionally and even innately talented in spotting business opportunities, business education can help uncover and develop various skills that are critical to starting and running a successful business venture.

Evidence from a study of high school students participating in an entrepreneurship education programme in Australia demonstrated significant impacts on entrepreneurial intentions both with respect to perceived desirability and feasibility of pursuing an entrepreneurial career, regardless of prior experience (Gibb, 2007). InKenya, entrepreneurship Educationis introduced to the curriculum at post-secondary levels i.e tertiary institutions and universities (Maina, 2006). The Government of the Republic of Kenya recognizes the strategic importance of improving the overall education level of Kenyans within the context of poverty reduction and economic growth. Science, technology and innovation sector seeks to achieve key objectives of enhanced access, equity relevance and quality of outcomes in higher education, science, technology and innovation. One of the problems facing the Kenyan economy is unemployment. This is due to low economic growth, corruption, nepotism and the negative attitude towards entrepreneurshipGoK (2011)

There seems to be some disagreement between the academic and practical fields on how to approach the teaching of entrepreneurship (Jones, 2006; Neck \& Greene 2011). There is also a contradiction within academia regarding how to 


\section{International Journal of Science and Research (IJSR) \\ ISSN (Online): 2319-7064}

Index Copernicus Value (2015): 78.96 | Impact Factor (2015): 6.391

understand entrepreneurial pedagogy (Kyrö, 2005)Research has established that entrepreneurs learn differently from others (Fredrick, 2007; Gatchalian, 2010), it is upon this background that this study seeks to examine the pedagogy of entrepreneurship education and its contribution in creating entrepreneurial propensity in Kenya.

\section{Statement of the Problem}

Nations that have embraced entrepreneurship have made good progress in addressing the problem of unemployment, and achieved impressive results (Alakbarov, 2010). Entrepreneurship education is ubiquitous because it lends itself to application in all career fields, permeating the whole socio-economic fabric, enhancing profitable tapping into human potential, and exploiting available natural resources (ROK, 2005;Maina, 2006)

Kenya ranks among the most entrepreneurial economies in East Africa, an environment characterised by a relatively high level of provision of skills required for enterprise development (Garavan and O'Cinneide, 1994). This orientation is informed by concepts of entrepreneurship education, which acknowledge that although some people may be exceptionally and even innately talented in spotting business opportunities, business education can help uncover and develop various skills that are critical to starting and running a successful business venture. Entrepreneurially focused business education must aim to deliver technical skills, business management skills and personal entrepreneurial skills as important learning outcomes.

The Government of the Republic of Kenya recognizes the strategic importance of improving the overall education level of Kenyans within the context of poverty reduction and economic growth (GoK, 2011). While there is a great deal of literature on entrepreneurship education and case studies of entrepreneurial learning, more profound investigations into entrepreneurial pedagogy are rare. There seems to be some disagreement between the academic and practical fields on how to approach the teaching of entrepreneurship (Jones, 2006; Neck \& Greene 2011). There is also a contradiction within academia regarding how to understand entrepreneurial pedagogy (Kyrö, 2005)Research has established that entrepreneurs learn differently from others (Fredrick, 2007; Gatchalian, 2010). This study sought to examine the pedagogy of entrepreneurship education and its contribution in creating entrepreneurial propensity in Kenya.

\section{Objectives ofthe Study}

1) To determine contribution of Mass instruction techniques entrepreneurship pedagogy on entrepreneurial propensity.

2) To examine influence of active experimentation method of entrepreneurship pedagogy on entrepreneurial propensity.

3) To assess effect of doing experience method of entrepreneurship pedagogy on entrepreneurial propensity.

\section{Theoretical Framework}

This study is anchored on the tradition of experiential learning (Bloom 1959; Hilgard 1980; Kolb 1984) and a pragmatic appreciation of the delivery options (Elton, 1977) for educators working with large groups. Kolb (1984) described learning as "the process whereby knowledge is created through the transformation of experience." In other words experience is the source of learning and development. According to Kolb learning is a four stage cycle process. It occurs when students engage in some activity, reflect upon the activity, derive insight from the analysis, and incorporate the result through a change in understanding. This is experiential learning. Most critically these models explore the range of pedagogies that can be used in a programme to deal with the Affective and Conative as well as the Cognitive aspects of learning (Kyro2006). These provide an overview of how students learn and how an educator can support learning through the choice of an appropriate instruction method.

\section{Empirical Framework}

Hytti and $\mathrm{O}^{\circ e}$ Gorman (2004) argue that there are many ways to offer entrepreneurship education depending on the objectives of such education. If the objective of the education is to increase the understanding of what entrepreneurship is about, the most effective way to accomplish the objective is to provide information through public channels such as media, seminars, or lectures. These methods are effective in terms of sending the relevant information to a broader population in a relative short time period. If the objective is to equip individuals with entrepreneurial skills, which are applicable directly to work, the best way is to provide education and training that enable individuals to involve directly in the entrepreneurial process, such as industrial training. Lastly, if the objective of the education is to prepare individuals to act as entrepreneurs, the most effective technique is to facilitate experiments by trying entrepreneurship out in a controlled environment, for instance through business simulation or role playing (Ahmad et al, 2004).

It seems that most authors categorize teaching methods into two groups, which are termed "traditional methods" (comprising normal lectures) and "innovative methods" (which are more action-based), also known as "passive methods" and "active methods", respectively (Mwasalwiba, 2010). Compared with passive methods, active methods according to Bennett (2006) are those that require the instructor to facilitate learning, not to control and apply methods that enable students' self-discovery. The three most used methods are: lectures, case studies, group discussions. These are actually the same methods used in other businessrelated courses, which according to Bennett (2006) are passive and less effective in influencing entrepreneurial attributes. Fiet (2000a) explains that instructors rely on lecture-based methods because they can be easily accomplished, and also because they require less investment. Other methods used, but not as common as the previous group, include: business/computer or game 


\section{International Journal of Science and Research (IJSR) \\ ISSN (Online): 2319-7064}

Index Copernicus Value (2015): 78.96 | Impact Factor (2015): 6.391

potential for stimulating entrepreneurial attributes and insight and equipping participants for action. In particular, it is focused upon practicingbehaviours, developing skills and reinforcing attributes associated with being an enterprising person. It is based upon the assumption that all persons have some capacity for behaving entrepreneurially and enhancing that capacity. There is need for a strong emphasis upon teaching, ,for ${ }^{\text {ee }}$ as opposed to ,about ${ }^{\text {ee }}$ (Levie 1999).

The focus of learning has moved from the past - the models of mass instruction (Elton 1977) in which the educator take the place of the ,sage on the stage ${ }^{\text {ee }}$ transmitting knowledge through mass instruction - to the ,future ${ }^{e e}$ - where there is a need for students to resolve problems and respond with creativity and insight. critical shifts that demand an approach to teaching, which reviews the role of the student; the approach and focus of the learning and, ultimately the role of the educator, to ,guide on the side $^{e e}$ - a supportive facilitator of learning, rather than the knowledge ,expert (Gibb 2007)
Entrepreneurial learning focuses upon the development of the entrepreneurial mindset, and draws upon the development of higher level skills affective, cognitive and Conative to achieve this. Elton's classifications (1977) indicate that the extent to which skill level is developed is dependent upon the selection of the most appropriate delivery method. This suggests that even with large class sizes, interactive engagement, which follows a model of experiential learning (Kolb 1984; Race 2007) through small discussions, voting, polls and questions to speakers can support higher levels of student engagement. The traditions of education across the world have been rooted in mass instruction techniques; however entrepreneurial learning draws extensively from the use of small groups as entrepreneurial outcomes are best secured in this delivery method

\section{Conceptual framework}

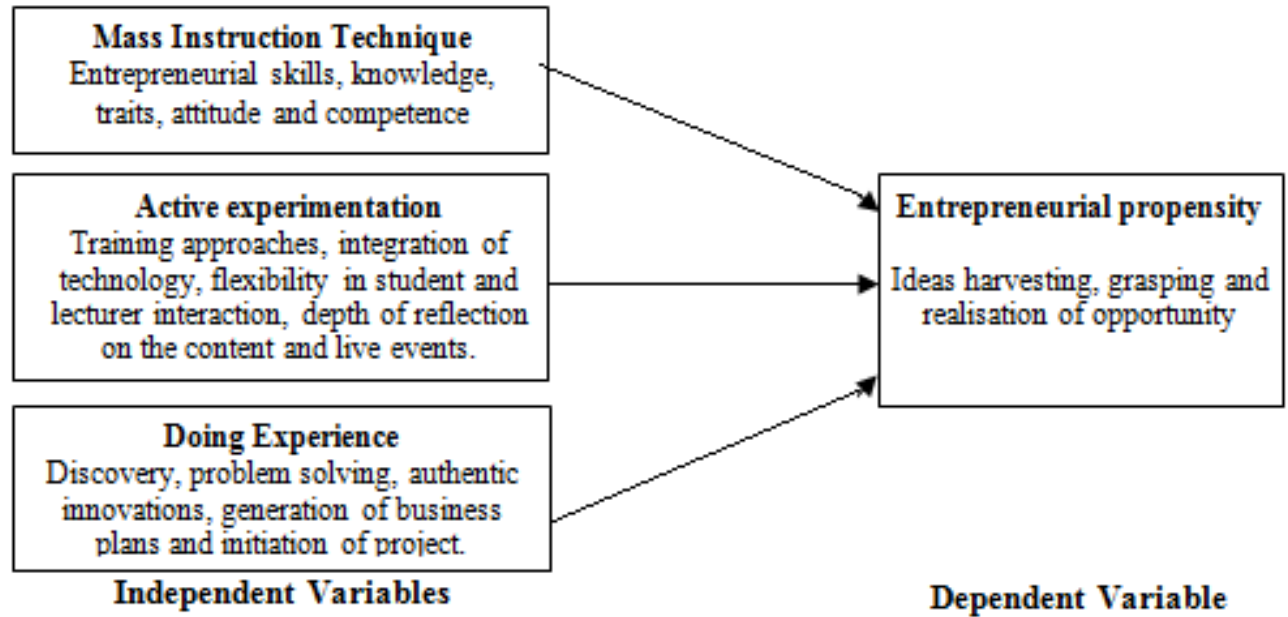

\section{Research Methodology}

The study adopted correlational field study design which examines relationship between concepts (Walliman, 2011). The design was applied to examine the association between pedagogy of entrepreneurship education and entrepreneurial propensity. The study sought to assess the variation of variables so that the degree of relationship between them can be determined. The target population was both the entrepreneurship education lecturers and graduates of entrepreneurship programme whograduated in the last two years ( Year 2014 and 2015) from Technical institutions and public universities within Nairobi County.

The sample size was determined by application of Zikmund (2010), formula which states that;

$$
\mathrm{n}=\frac{\mathrm{z}^{2} \mathrm{pq}}{\mathrm{e}^{2}}
$$

\section{Where}

$\mathrm{Z}=$ table value from the normal table

$\mathrm{p}=$ probability of success (male dominated proportion).

$\mathrm{q}=(1-\mathrm{p})$ probability of failure (female dominated proportion).

$\mathrm{e}=$ allowed error
The study engaged systematic random sampling technique to select forty students from public universities and ten lecturers. The study sample size constituted ten lecturers and forty graduates - a sample size of fifty. Semi- structured questionnaire and observation guide (for triangulation of the results) were personally administered to the respondents to collect data.

Descriptive statistics: frequencies, percentages, measures of central tendency, measures of dispersion, graphs, and tables were used to analyze data. For inferential analysis,multinomial logistic regression was used to analyze the relationship between Pedagogy of entrepreneurship education and entrepreneurship propensity.

\section{Results and Discussions}

Mass Instruction Technique Entrepreneurship Pedagogy The objective of this study was to determine contribution of Mass instruction technique entrepreneurship pedagogy on entrepreneurial propensity. The parameters formeasuring Entrepreneurship propensity were Entrepreneurial skills, knowledge, traits, attitude and competence. The relationship between the various measures of mass instruction technique entrepreneurship pedagogy and propensity of 


\section{International Journal of Science and Research (IJSR) \\ ISSN (Online): 2319-7064}

Index Copernicus Value (2015): 78.96 | Impact Factor (2015): 6.391

entrepreneurship was derived after running the score on each variable in a multinomial logistic regression at 5\% level of significance. The overall $\mathrm{p}$ value for the mass instruction technique entrepreneurship pedagogy in Entrepreneurship propensitywas 0.000 which was less than 0.05 ; implying that there is a significant influence of mass instruction technique entrepreneurship pedagogy in Entrepreneurship propensity.

\section{Doing Experience Method of Entrepreneurship Pedagogy}

The parameters of doing experience method of entrepreneurship pedagogy were discovery, problem solving, and authentic task, generation of business plans and presentation of project work. The measure for doing experience method of entrepreneurship pedagogywas asa resultof aggregating the total score of each of the respondent in a Likert scale. The relationship between the various measures of doing experience method of entrepreneurship pedagogy and entrepreneurship propensity was as a result of regressing the two variables in a multinomial logistic regression at 5\% significance level. The combined effect of doing experience method of entrepreneurship pedagogy was obtained by adding the total parameters in the variable and a regression analysis against the total score for entrepreneurship propensity. The overall $\mathrm{p}$ value for doing experience method of entrepreneurship pedagogy was 0.000 which was less than 0.05 implying a significant influence of doing experience method of entrepreneurship pedagogy on entrepreneurship propensity. It can therefore be concluded that doing experience method of entrepreneurship pedagogy significantly influence entrepreneurial propensity.

\section{Active Experimentation Method of Entrepreneurship Pedagogy}

The third objective of the study was to establish how active experimentation method of entrepreneurship pedagogy influences entrepreneurial propensity. The two variables were measured differently and their relationship was later sought. The relationship between the various measures of active experimentation method of entrepreneurship pedagogy and entrepreneurship propensity resulted from the regression of the two variables in a multinomial logistic regression at $5 \%$ level of significance. The combined effect of active experimentation method of entrepreneurship pedagogy was derived from the total parameters score in the variable regressed against the total score for entrepreneurship propensity. The overall $\mathrm{p}$ value for active experimentation method of entrepreneurship pedagogy was 0.000 which was less than the significant value at $5 \%$; This indicates a significant influence ofactive experimentation method of entrepreneurship pedagogy on entrepreneurship propensity.

\section{References}

[1] Alakbarov, I. (2010) Azerbaijan's Success Story on Sustainable Entrepreneurship Development Through Adoption of Policies, Financing and Innovative Strategies, InInternational Conference on Policies to Address Financing and Entrepreneurial Challengesin High-growth Innovative Firms (2-4 June 2010), Helsinki
[2] Alberti,A., Sciascia,

$$
\text { B., }
$$

\&Poli.

(2004)

Entrepreneurship Education: Notes on an Ongoing Debate. In: 14th Annual IntEnt Conference. University of Napoli Federico II, Italy.

[3] Bird, B. J. (2002-2003. Learning Entrepreneurship Competences: the self-directed learning approach.International Journal of Entrepreneurship Education, 1(2), pp. 203-227.

[4] Carrier, C. (2007). Strategies for Teaching Entrepreneurship: What else beyond lectures, case studies and businessplan? In Fayolle, A. (ed), Handbook of Research in Entrepreneurship Education. 1 (pp. 143 159). Chetelham (UK): Edward Elgar Publishing.

[5] Cooper, S., Bottomley, C. and Gordon, J. (2004). Stepping out of the Classroom and up the Ladder of Learning:An experimental learning approach to entrepreneurship education, Industry and Higher Learning, 18(1), pp.11-22.

[6] Dana, L.P. (1993) An International Survey of Entrepreneurship Education, Journal of enterprising culture, 1(1), pp. 67-92.

[7] Ehrste'n, M. and Kjellman, A. (2001). Rethinking Education: from homo industialis to homo entreprenaurusPreliminäraforskarrapporter, $\mathrm{Nr} 218$. Åbo: Åboakademi.

[8] Formica, P. (2002). Entrepreneurial Universities: the value of education in encouraging entrepreneurship. Industri and Higher Education, 16(3), pp. 167-175.

[9] Frederick, H. H. (2007) Blended Learning in Entrepreneurship Education in the Asia-Pacific: A Grounded Approach to Entrepreneurship Pedagogy,InSmall Enterprise Conference, 23- 26 Sep 2007, Unitec Business School, Auckland

[10] Gatchalian, M. L. (2010) An In-depth Analysis of the Entrepreneurship Education in the Phillipines: An Initiative Towards the Development of a Framework for a Professional 26 Teaching Competency Program for Entrepreneurship Educators, The International Journal of Research and Review, Vol 5, pp.51-73.

[11] Garavan, T. and O'Cinneide, B. (1994). Entrepreneurship education and training programmes. Journal of European Industrial Training, 18(8),3-12.

[12] Gorman, G., Hanlon, D., \& King, W. (1997). Some research perspectives on entrepreneurship education, enterprise education, and education for small business management: A ten-year literature review. International Small Business Journal, 15, 56-77

[13] Hindle, K. (2007). Teaching Entrepreneurship at the university: from the wrong building to the right philosophy in Fayolle, A. Handbook of Research in Entrepreneurship Education. 1. Chetelham (UK): Edward Elgar Publishing.

[14] Honig, B. (2004). A contingency model of business planning, Academy of Management Learning and Education.3(3).258-273.

[15] International Labour Organisation (2004).Facilitating Youth Entrepreneurship Programme.SEED Paper 45. Geneva: ILO Jack, S.L., \& Anderson, A.R. (1998). Entrepreneurship Education within the Condition of Entreprenology.In: Proceedings of the Conference on Enterprise and Learning, Aberdeen.

[16] Fayolle A. (2009). Entrepreneurship Education in Europe: Trends and Challenges, OECD LEED 


\section{International Journal of Science and Research (IJSR) \\ ISSN (Online): 2319-7064 \\ Index Copernicus Value (2015): 78.96 | Impact Factor (2015): 6.391}

Programme, universities, innovation and entrepreneurship: good practice workshop. [Online] Available:

http://www.oecd.org/dataoecd/11/36/43202553.pdf.

[17] Kolb, D. A. (1984) Experiential Learning: Experience as the Source of Learning and Development, Prentice Hall, New Jersey

[18]Laukkanen, M. (2000). Exploring Alternative Approaches in High-level Entrepreneurship Education: creating micro-mechanisms for endogenous regional growth, Entrepreneurship and Regional Development, 12(1), pp. 25-47

[19]Levie, J. (1999) 'Enterprising Education in Higher Education in England'. Department for Education and Employment.pp 40.

[20] Maina, R. (2006, June Friday, 2nd) Stimulating Youth Entrepreneurship in Kenya, Structured Qualitative Methods EDMP 638 . Nairobi: (Unpublished).

[21] Mansor, M., \& Othman, N. (2011) CoBLAS: Inculcating Entrepreneurial Culture among Higher Education Institutions' Students, International Journal of Social Science and Humanity, Vol. 1, No. 1, 86-91

[22] Plaschka, P.R. \&Welsch, H.P. (1990). Emerging structures in entrepreneurship education: Curricular designs and strategies. Entrepreneurship Theory and Practice, 14(3), 55-71.

[23] Pittaway L and Cope J (2007). Entrepreneurship Education: A Systematic Review of the Evidence International Small Business Journal 25(5): 479-510.

[24] Rae, D. and Carswell, M. (2001). Towards a Conceptual Understanding Of Entrepreneurial Learning, Journal of small business and enterprise development, 8(2), pp. $150-158$.

[25]ROK. (2005) Sessional Paper No. 2 of 2005 on Development of Micro and Small Enterprises for Wealth and Employment Creation for Poverty Reduction, Government Printer, Nairobi.

[26] Sherman, P., Sebora, T., \&Digman, L. (2008) Experiential Entrepreneurship in the Classroom: Effects of Teaching Methods on Entrepreneurial Career Choice Intentions, Journal of Entrepreneurship Education. Vol. 11, pp. 29-42.

[27] Smith, A. M., \& Paton, R. A. (2011) Delivering enterprise: A collaborative International Approach to the Development, Implementation and Assessment of Entrepreneurship,International Journal of Entrepreneurial Behaviour \& Research, 17 (No. 1), 104118.

[28] Solomon, G.T., Duffy, S., \&Tarabishy, A. (2002). The state of entrepreneurship education in the United States: A nationwide survey and analysis. International Journal of Entrepreneurship Education, 1(1), 65-86. xxvii

[29]Pittaway L and Cope J (2007). Entrepreneurship Education: A Systematic Review of the Evidence International Small Business Journal 25(5): 479-510.

[30] Timmons, J.A. (1994). New Venture Creation: Entrepreneurship for the 21st Century. Burr Ridge: Irwin. See also: Plaschka, P.R. \&Welsch, H.P. (1990). Emerging structures in entrepreneurship education: Curricular designs and strategies. Entrepreneurship Theory and Practice, 14(3)55-17

[31] White. R.J., Hertz, G.T., \& D'Souza, R., (2010). Entrepreneurship Education Pedagogy: Using
Technology to Learn About Fundable Business Plans. in: 14th Annual Conference (NCIIA), San Francisco.

[32] Gibb, A.A. (2007). Creating the entrepreneurial university: do we need a different model of entrepreneurship. In Fayolle, A. (ed), Handbook of research in Entrepreneurship Education 1, 67-104. London: Edward Elgar. 